\title{
Nota Editoral
}

\author{
ARQUIVOS DE NEURO-PSIQUIATRIA mantém a \\ liderança entre os periódicos da área da saúde que \\ adotam os progressos da comunicação impressa. Muito \\ se caminhou na última década e há muito mais a realizar \\ daqui para frente. Mudanças contínuas ocorrem em \\ todas as áreas da comunicação científica, algumas das \\ quais para facilitar os sistemas internacionais de \\ catalogação e de indexação. Entre elas, o formato.
}

\section{ARQUIVOS DE NEURO-PSIQUIATRIA manteve o mesmo formato desde seu primeiro número (1943). Agora, ganha nova apresentação. A partir deste número (Março 2001), a revista passa a aparecer em 21 x $28 \mathrm{~cm}$ e com o texto dos artigos distribuído em duas colunas por página.}

A equipe que cuida da produção da revista espera que os leitores aprovem o novo formato de Arquivos de Neuro-Psiquiatria, 


\section{Editorial Note}

ARQUIVOS DE NEURO-PSIQUIATRIA is a journal with a leading position among Brazilian health sciences periodicals which are sensitive to progress in printed communication. Many advances were introduced in the journal during the past decade and there is much to do. Changes in scientific communication succeed one the other continuously and several of them were developed in order to improve international catalogue and index systems. Among them, the format.

\section{ARQUIVOS DE NEURO-PSIQUIATRIA has}

maintained the same format since the first number (1943). From now on (March 2001) the journal appears in $21 \times 28 \mathrm{~cm}$ and page distribution in two columns for articles' texts.

The staff of the journal is sure of the approval of the readers to new format of Arquivos de Neuro-

\section{Psiquiatria,}

Antonio Spina-França 